хоцяшихъ для такого льчченія, авторъ выбраль алюмноль, въ виду его свойства, не разрушая тканей, г.ту́ого проникать въ толщу ихъ.

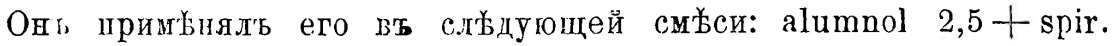
vini rectificatissimi 25,0 t tinct. jodi 25,0 . Введеніе этой см эеи въ цолость матки цьла.гос помощью Брауновской спринцовки, иногда сь ирелварительнымъ үасширеніемь канала пейки. Смъьсь подогрьвалась до 280. Авторь ошисываеть пять случаевь усињшнаго примьыенія этого средства. Всћ случаи сь острыми или обострившимися явленіями: болями, бьлями (гонококки), выпотомь въ около маточныхъ пространствахъ, и въ одномъ случаб съ опредьленной әтіологіей. Одна больная льчилась аббулаторно. Л屯ченіе продолжалось отъ одной недъли по двухъ мъсяцевъ. Одной больной было сдтлано всего 24 впрыскиванія. Выводы автора: впрыскиванія алюмнола сокращаю'ь теченіе остраго восиалительнаго стадія бользни, понижають температуру тьла и ослабляють боли; всасываніе выпотовъ ускоряется, явленія әндометрита ослабляются, ири чемъ гнойный секреть становится слизистымъ.

\title{
Н. Какуткинъ.
}

148. В. А. Петровъ.-Случай фобороміомы. (Отд. отт. изъ Трудовъ Физико-Медиц. Общ. въ Саратовь, за 1894 г.).

Крестьянка 27 льть, больна два года, жалуется на ростущую опухоль. Посльдняя, съ голову взрослаго, принадлежить тьилу и дну матки, вполнь подвижна. Сдылано надвлагалищное отсъчченіе матки съ прицатками съ помощью жтута. Ампутапіонный разрьзъ пришелся на верхнюю часть полости матки. Полость прижжена $10 \%$ ростворомь карболовой кислоты. На культю наложены три яруса пвовъ: два на мышшы и одинъ на брюшину. Съмянныя артеріи перевязаны отдъльно. Посльоперапіонное время пропло глацко.

H. Какуикинъ.

\section{9. М. К. Гайрабөтовъ. - Случай полнаго отсутствія} матки.-(Медиц. Обозр., 1895 г., № 13).

Замужнял и бездттная. Мъсячныхъ ни разу не им'љла, но разъ въ мисяпь обычное у нея шелушеніе надкожиды всего тьла усиливалось, причемь больла голова в'ь теченіи 3-4 дней. Половыя снопенія всегда были безразличны. Наружные половые органы безь особенныхъ отклоненій. Влагалище длиной около $\imath^{1} / 2$ верпковъ. В'ь сводь его протупывается бугорокь съ горошину. Внутреннихъ половыхъ органовъ нЊтъ. Больная умерла отъ бугорчатки легкихъ и при вскрытіи ея трупа шрижизненное 